\title{
Heparan sulfates and heparins: similar compounds performing the same functions in vertebrates and invertebrates?
}

H.B. Nader ${ }^{1}$, S.F. Chavante? E.A. dos-Santos' , F.W. Oliveira? J.F. de-Paiva², S.M.B. Jerônimo², G.F. Medeiros ${ }^{3}$, L.R.D. de-Abreu²,

E.L. Leite ${ }^{2}$, J.F. de-Sousa-Filho2 R.A.B. Castro ${ }^{1}$, L. Toma ${ }^{1}$, I.L.S. Tersariol ${ }^{4}$, M.A. Porcionatto $^{1}$ and C.P. Dietrich ${ }^{1}$

\author{
1 Departamento de Bioquímica, Escola Paulista de Medicina, \\ Universidade Federal de São Paulo, São Paulo, SP, Brasil \\ Departamentos de ${ }^{2}$ Bioquímica e ${ }^{3} \mathrm{O}$ ceanografia, \\ Universidade Federal do Rio Grande do Norte, Natal, RN, Brasil \\ ${ }^{4}$ Centro de Ciências Biomédicas, U niversidade de Mogi das Cruzes, \\ Mogi das Cruzes, SP, Brasil
}

\section{Correspondence}

H.B. Nader

Departamento de Bioquímica UNIFESP

Rua 3 de Maio, 100

40 andar

04044-020 São Paulo, SP

Brasil

Presented at the 5th Brazilian Symposium on Extracellular Matrix - SIMEC, Angra dos Reis,

RJ, Brasil, September 7-10, 1998.

Research supported by FAPESP, CNPq, CAPES and FINEP.

Received October 19, 1998 Accepted November 10, 1998

\section{Abstract}

The distribution and structure of heparan sulfate and heparin are briefly reviewed. Heparan sulfate is a ubiquitous compound of animal cells whose structure has been maintained throughout evolution, showing an enormous variability regarding the relative amounts of its disaccharide units. Heparin, on the other hand, is present only in a few tissues and species of the animal kingdom and in the form of granules inside organelles in the cytoplasm of special cells. Thus, the distribution as well as the main structural features of the molecule, including its main disaccharide unit, have been maintained through evolution. These and other studies led to the proposal that heparan sulfate may be involved in the cell-cell recognition phenomena and control of cell growth, whereas heparin may be involved in defense mechanisms against bacteria and other foreign materials. All indications obtained thus far suggest that these molecules perform the same functions in vertebrates and invertebrates.

\section{Heparan sulfates from mammalian and other vertebrate tissues}

Among the sulfated glycosaminoglycans, heparan sulfate, a ubiquitous cell surface component of mammals and other vertebrates, is the one that exhibits the highest structural variability according to the tissue and species of origin (1-12). This class of compounds comprises linear polymers composed of several distinct disaccharide units containing glucuronic or iduronic acid and glucosamine with $\mathrm{N}$ - and 6-O-sulfates and

\section{Key words}

- Heparin, occurrence and function

- Heparan sulfate, occurrence and function

- Heparin, invertebrates

- Heparan sulfate, invertebrates

- Heparin and heparan sulfate, structure
$\mathrm{N}$-acetyl substitutions. The presence of other disaccharide units, which occur in smaller proportions and contain sulfate attached to their uronic acid residues, has also been identified in heparan sulfates $(11,12)$. The order in which these disaccharide units occur in the molecule was first established for the heparan sulfate derived from rabbit endothelial cells in culture (11). Recently the total sequence of the disaccharides from bovine pancreas and the partial sequence of seven other heparan sulfates of mammalian origin have also been established $(8,13)$. It 
Figure 1 - Proposed structures of heparan sulfates from different mammalian tissues. R, Protein linkage region. IdoA, $\alpha-L-$ Iduronic acid; GlcA, B-D-glucuronic acid; GlcN, $\alpha$-D-glucosamine; GlcNAc, $\alpha$-D-N-acetylglucosamine; $\mathrm{S}$, sulfate. was concluded from these studies that all the mammalian heparan sulfates contain common structural features such as an $\mathrm{N}$-acetylated and an $\mathrm{N}$-sulfated domain consisting of glucuronic acid-containing disaccharides and a more sulfated region consisting of iduronic acid-containing disaccharides. A peculiar tetrasaccharide, namely GlcNAc- $(\alpha 1-4)$ IdoUA-( $\alpha 1-4)-G l c N S-(\alpha 1-4)-I d o U A$, positioned between the two regions, was identified in all the heparan sulfates analyzed. It was also shown that the non-reducing ends of the heparan sulfates contain the monosaccharides glucosamine $\mathrm{N}$-sulfate or glucosamine 2,6 disulfate $(13,14)$. Figure 1 summarizes these findings. Partial sequences of other heparan sulfates of different origins such as liver have also been recently described (12).

\section{Heparan sulfate in invertebrates}

By degradation with heparitinases and heparinase from Flavobacterium heparinum

\section{BOVINE PANCREAS}

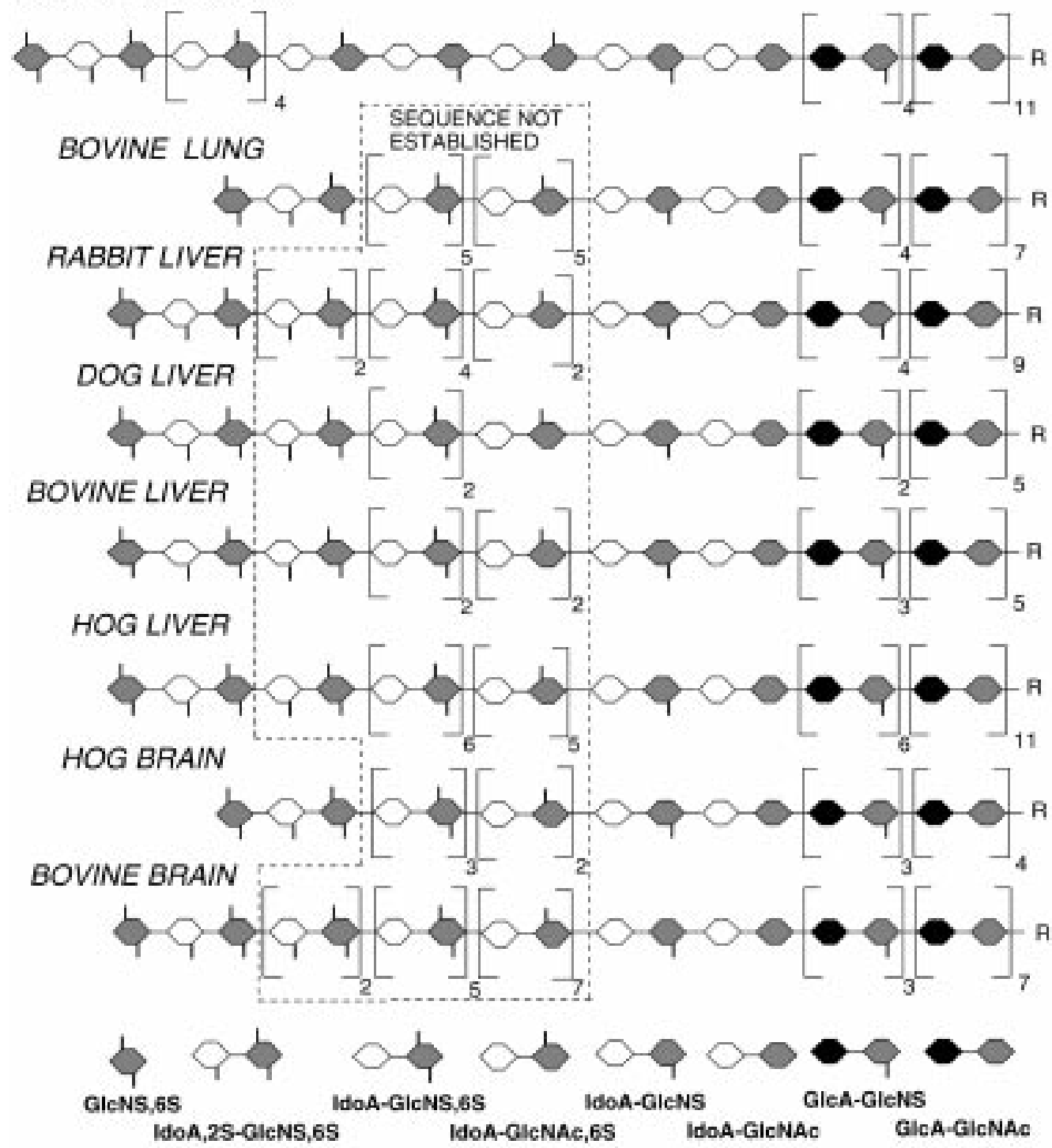


as well as electrophoretic migration in different buffer systems of the sulfated polysaccharides extracted from 22 species of the main classes of invertebrates, it was suggested that heparan sulfate-like and/or heparin-like compounds were present in all tissue-organized species analyzed (15). In a more recent survey of more than 50 invertebrates from different classes using the same methodology, it was shown that heparan sulfate was a ubiquitous compound as depicted in Figure 2 (Medeiros GF and Nader $\mathrm{HB}$, unpublished data). Other authors have also reported the presence of sulfated glycosaminoglycan-like compounds in some species of invertebrates (16-24).

These studies were further extended to different tissues of the mollusc Pomacea sp (25). Figure 3 shows that all tissues analyzed contain heparan sulfate-like, chondroitin sulfate and other unidentified polymers. A subsequent study using invertebrate species from habitats with different degrees of salinity, including a vicarious one (26), has shown that the concentration of heparan sulfate was directly proportional to the salt concentra- tion of the habitat (Figure 4).

Conclusive evidence that these heparan sulfates from invertebrates were undistinguishable from the ones of mammalian origin came from the isolation and purification of these compounds from three species of molluscs, namely, Pomacea sp, Tagelus gibbus and Anomalocardia brasiliana (27). Chemical analyses and enzymatic degradation have shown the presence of the same disaccharide units present in mammalian heparans. This was further confirmed by ${ }^{13} \mathrm{C}$ nuclear magnetic resonance spectrometry where, as shown in Figure 5, the heparan sulfate from the mollusc Anomantidae sp was undistinguishable from bovine pancreas heparan sulfate (28). As shown in Figure 6, the disaccharide units of this last heparan sulfate were also recently sequenced (29).

A heparan sulfate with some interesting characteristics was also isolated from the brine shrimp Artemia franciscana. This heparan sulfate, although containing the same disaccharide units found in the other vertebrate and invertebrate heparans, has a different electrophoretic migration. COSY and

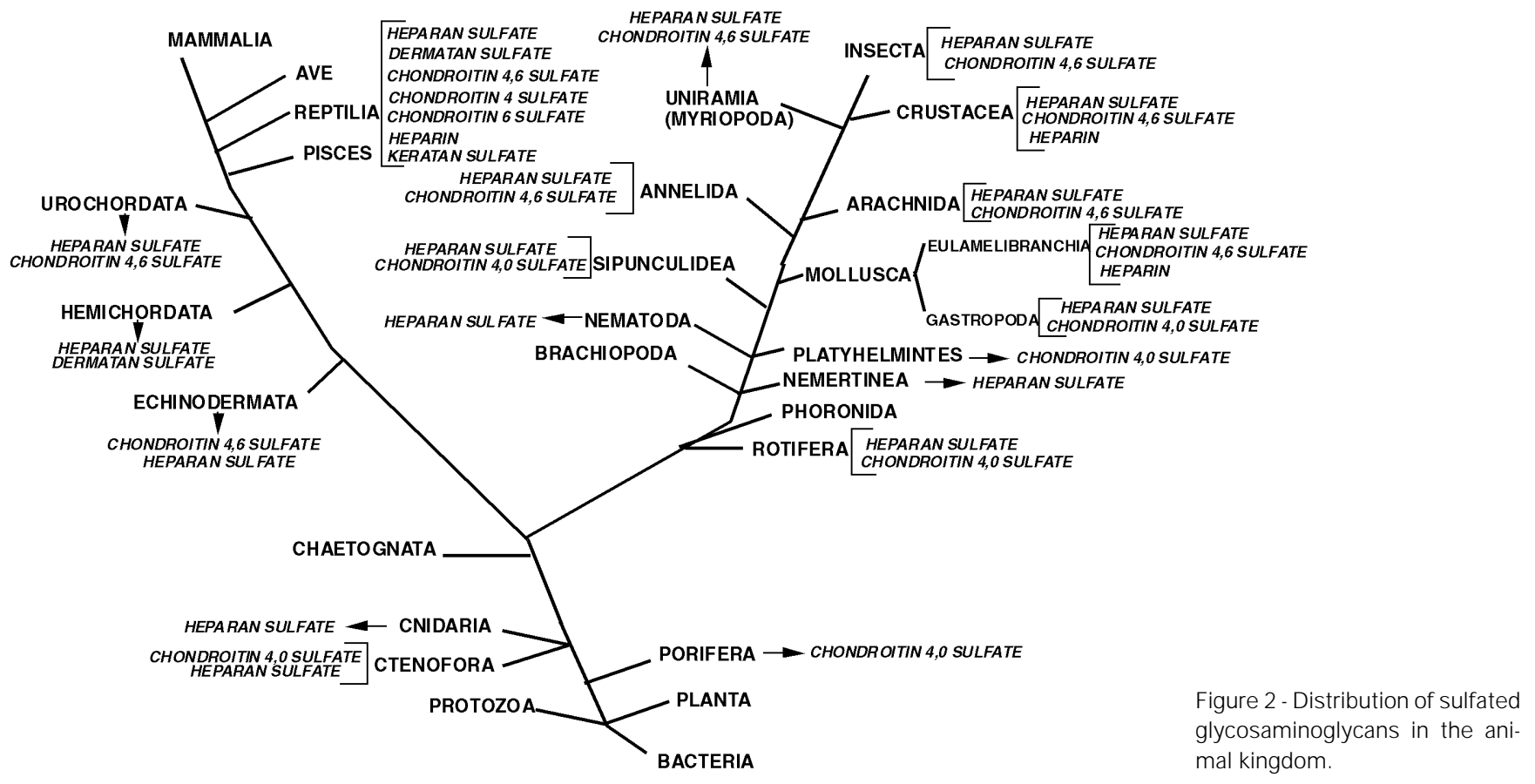



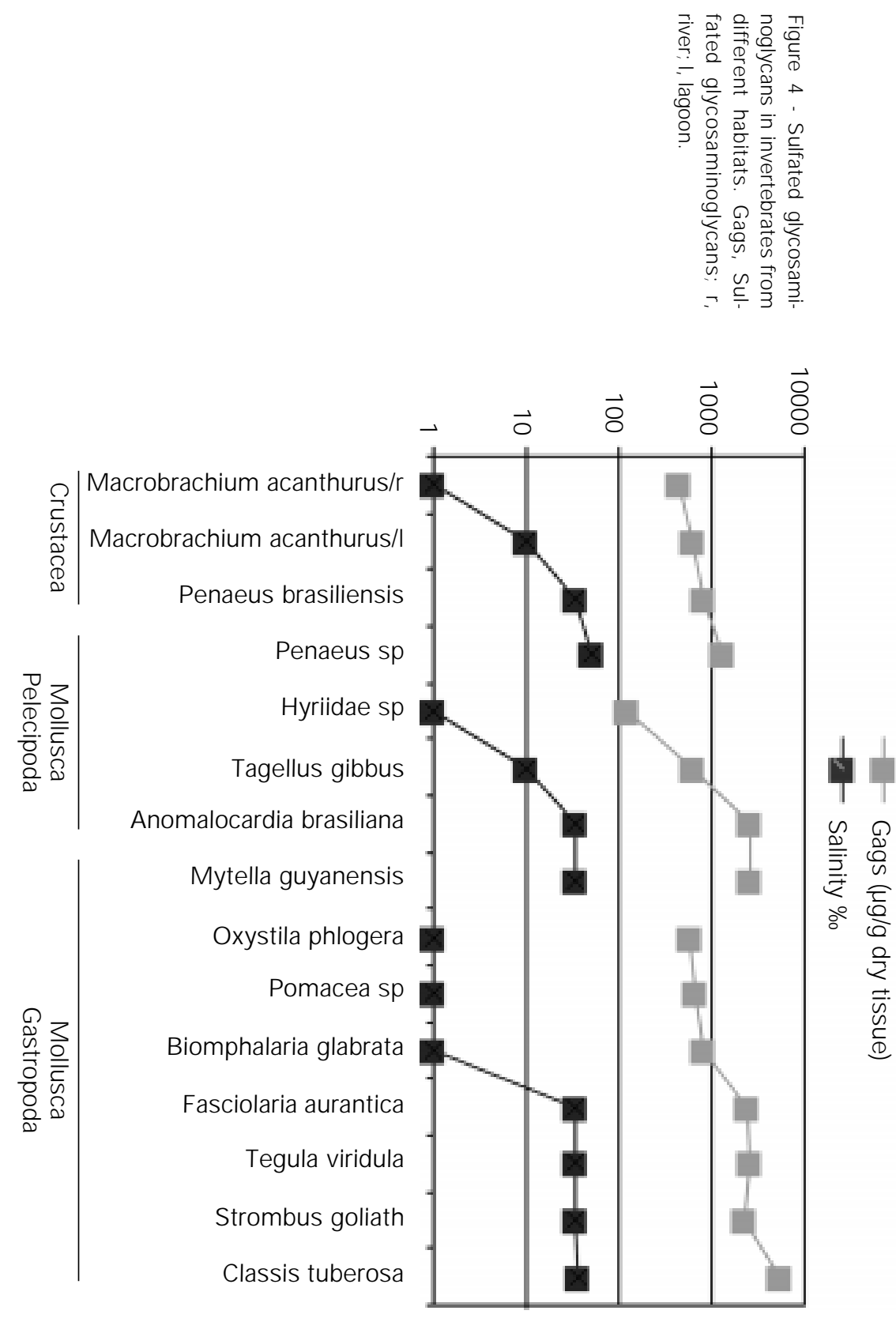
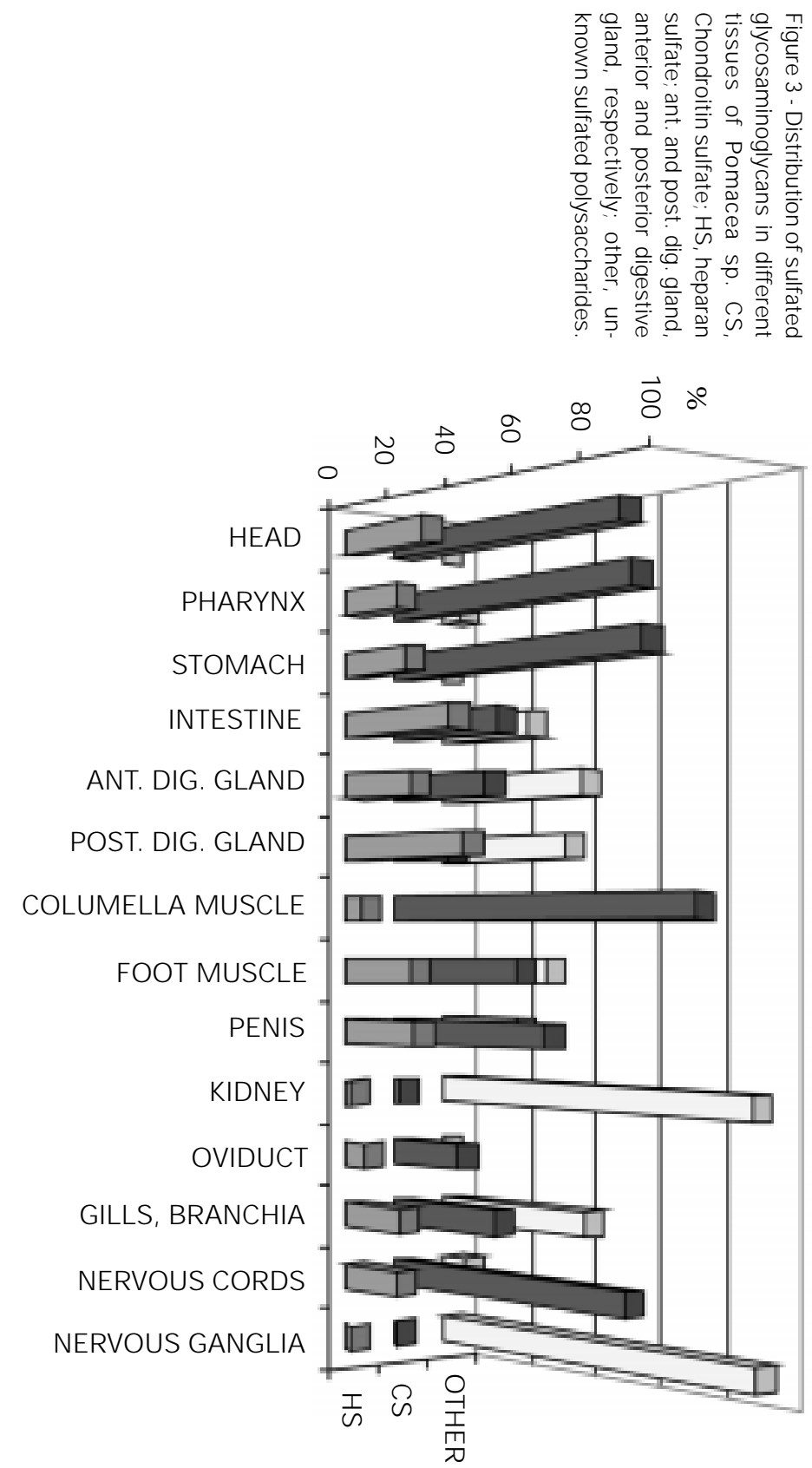
TOCSY nuclear magnetic resonance (NMR) spectroscopy has shown that this heparan was extremely rich in non-sulfated iduronic acid residues. It was also shown that the content of non-sulfated $\mathrm{N}$-acetylated disaccharide was low and accounted for 3-5\% of the total disaccharides of the molecule when compared to those of mammalian origin which accounted for $20-60 \%$ of the molecules (30). Another heparan sulfate isolated from the lobster Homarus americanus also showed different characteristics from those of heparan sulfates isolated from mammals, such as enrichment in disaccharides containing glucuronic acid residues (24).

\section{Heparin in mammalian and other vertebrate tissues}

Unlike heparan sulfate, heparin is present only in some tissues of vertebrates, as shown in Figure 7. For instance, heparin is absent or occurs in small amounts in brain, muscle and kidney of most species (for a review, see Ref. 31). Also, a wide variation in the concentration of heparin was observed when the same tissue of different species was compared. In general, heparin is usually present in tissues that are in direct contact with the environment such as lung, skin and intestine. Of particular significance was the observation that rabbit tissues do not contain heparin. Non-mammalian vertebrate tissues con-

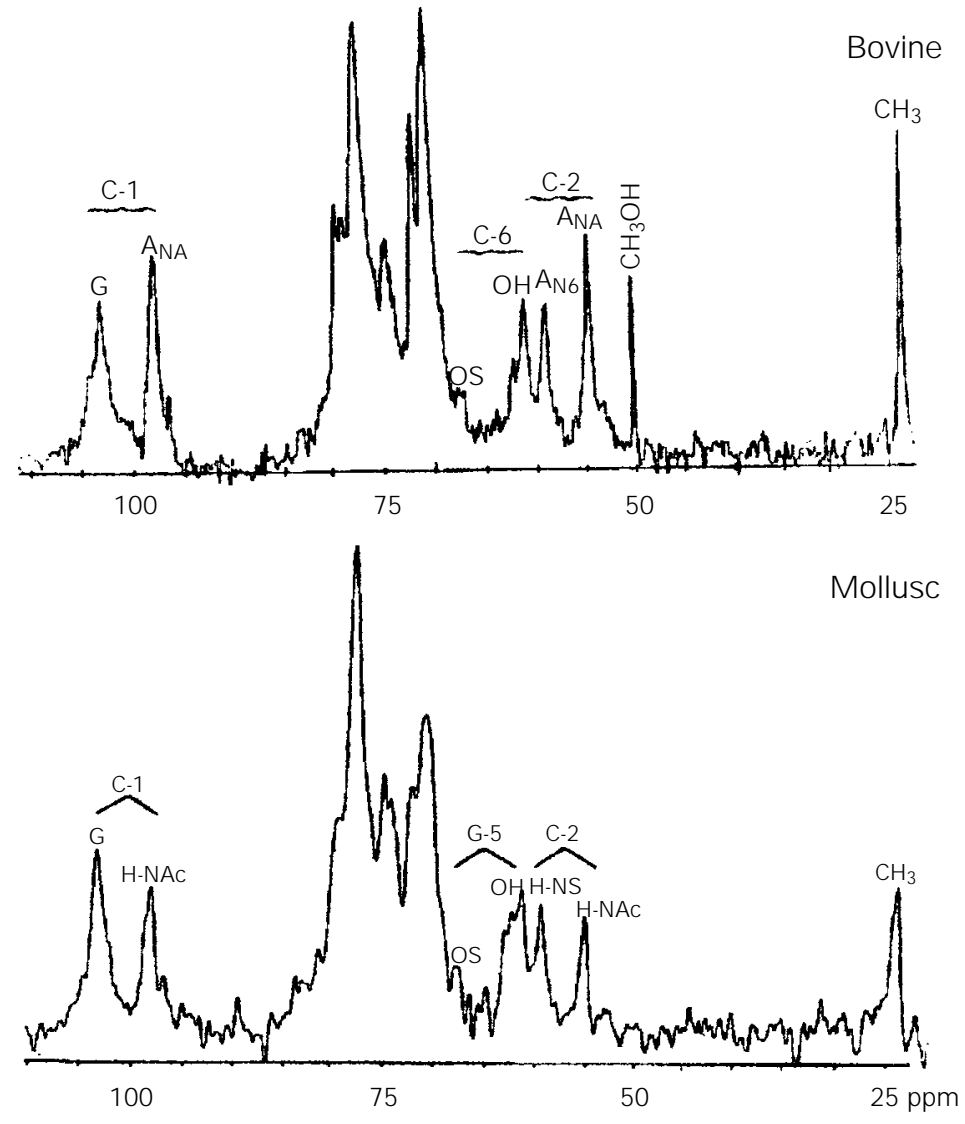

Figure 5 - $\left[{ }^{13} \mathrm{C}\right]-N M R$ of mammalian and mollusc heparan sulfates. G, Glucuronic acid; $\mathrm{H}-\mathrm{NAC}, \mathrm{A}_{\mathrm{NAC}}, \mathrm{N}$-acetylated glucosamine.

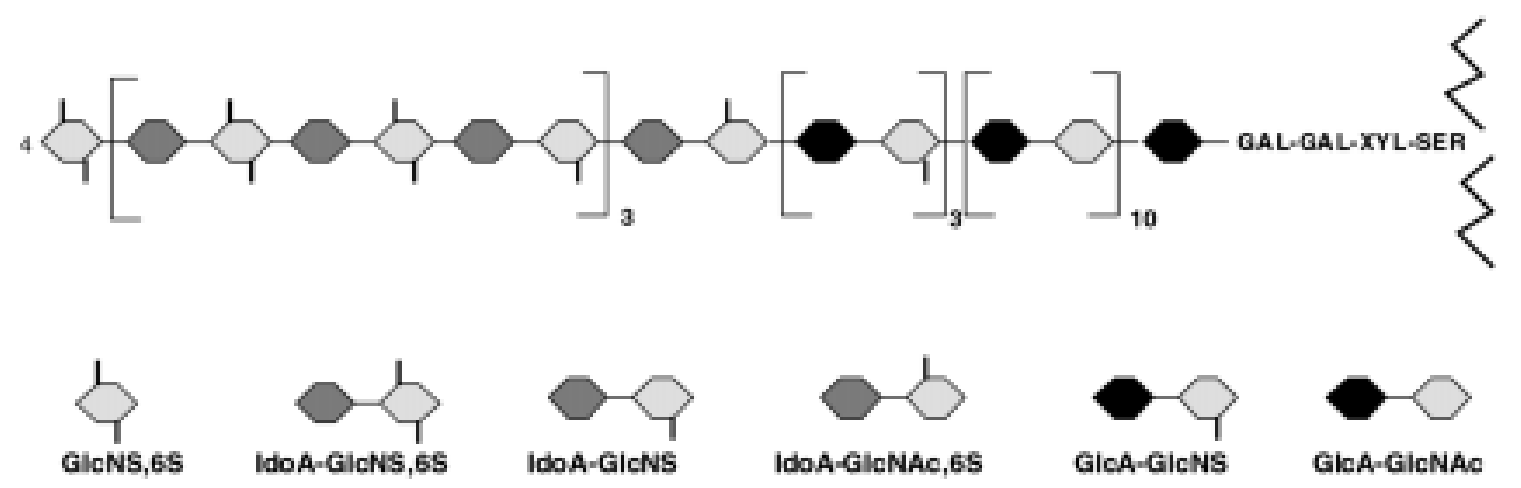

Figure 6 - Proposed structure of heparan sulfate from the mollusc Anomantidae sp. IdoA, $\alpha$-L-Iduronic acid; GlcA, B-Dglucuronic acid; GlcN, $\alpha$-D-glucosamine; GlcNAc, $\alpha$-D-N-acetylglucosamine; S, sulfate. 
Figure 7 - Distribution of heparin in vertebrate tissues.
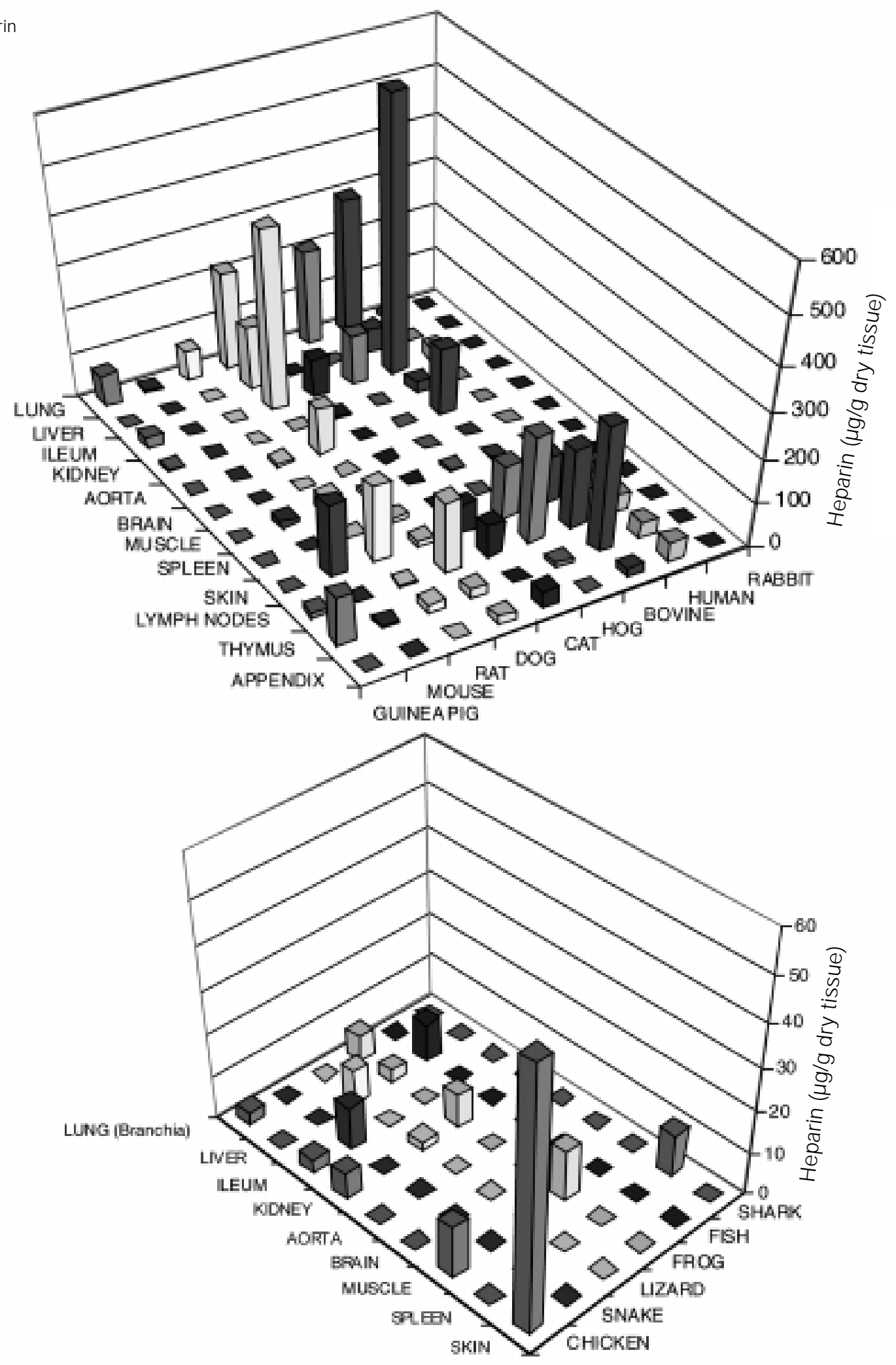
tain smaller amounts of heparin when compared to those of mammalian origin. An exception to this rule was the finding that chicken skin contains relatively large amounts of heparin (32).

\section{Heparin in invertebrates}

Suggestions for the presence of heparin in invertebrates came from the work of Burson et al. (33). These authors have isolated from the molluscs Spisula solidissima and Cyprinia islandica a polysaccharide denoted mactin, composed of glucuronic acid, glucosamine and sulfate, which possesses anticoagulant activity. Similar studies have shown that Anodonta sp (34), Anomalocardia brasiliana and Mesodesma donacium (15) contain similar polysaccharides.

Unlike heparan sulfate, heparin was only found in some species of invertebrates, e.g., molluscs and crustaceans (Figure 2). The distribution of heparin in different tissues of the mollusc Anomalocardia brasiliana (35) has revealed that the highest concentration of heparin was found in tissues that are in direct contact with the environment (Figure 8 ), similar to the distribution found for heparin in vertebrates. Histological examination of the tissues has shown that heparin is present in special cells forming granules, suggesting that the mollusc also contains mast cells (35).

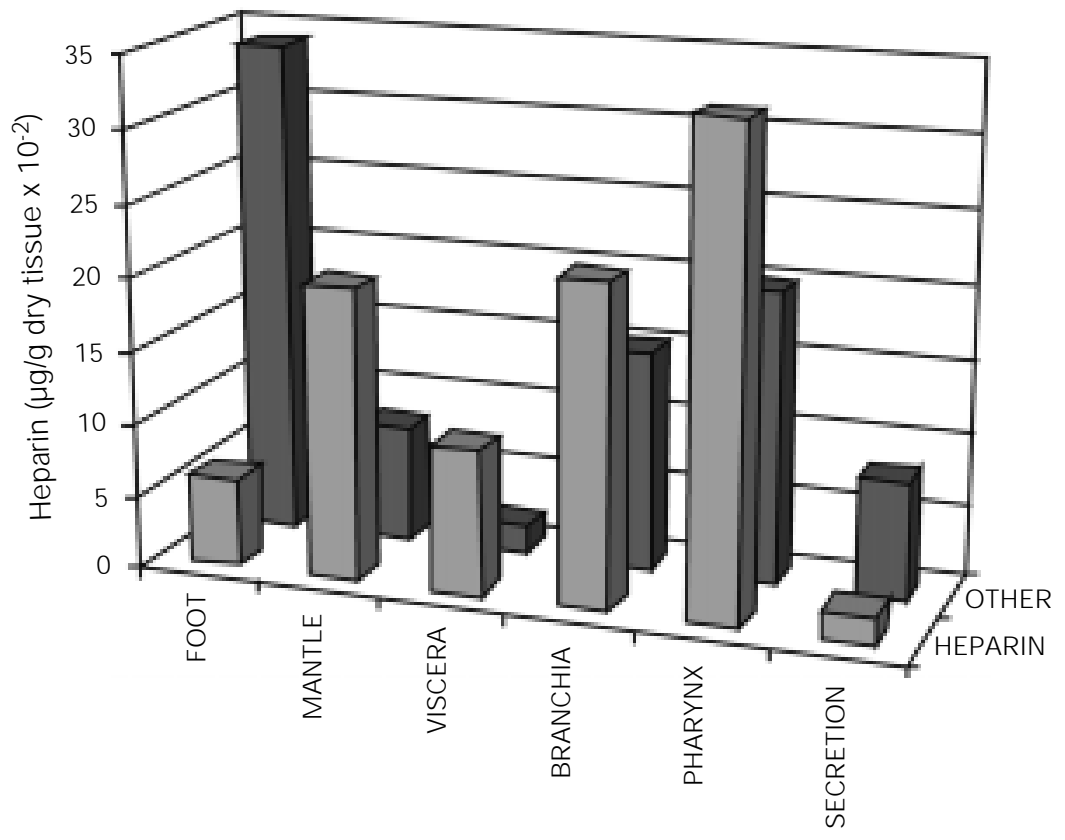

Figure 8 - Distribution of heparin in different tissues of the mollusc Anomalocardia brasiliana. Other, heparan sulfate, chondroitin sulfate and unknown sulfated polysaccharides.

Using heparinase and heparitinase II from Flavobacterium heparinum, it was possible to draw a general picture of the structure of heparin, as shown in Figure 9. Heparin seems to be composed of two different regions, one susceptible to heparinase whose action upon the compound produces a trisulfated disaccharide and sulfated tetrasaccharides, and another less sulfated region, which is susceptible to the action of heparitinase II. This last region seems to contain disaccharides with glucuronic acid residues, as judged by
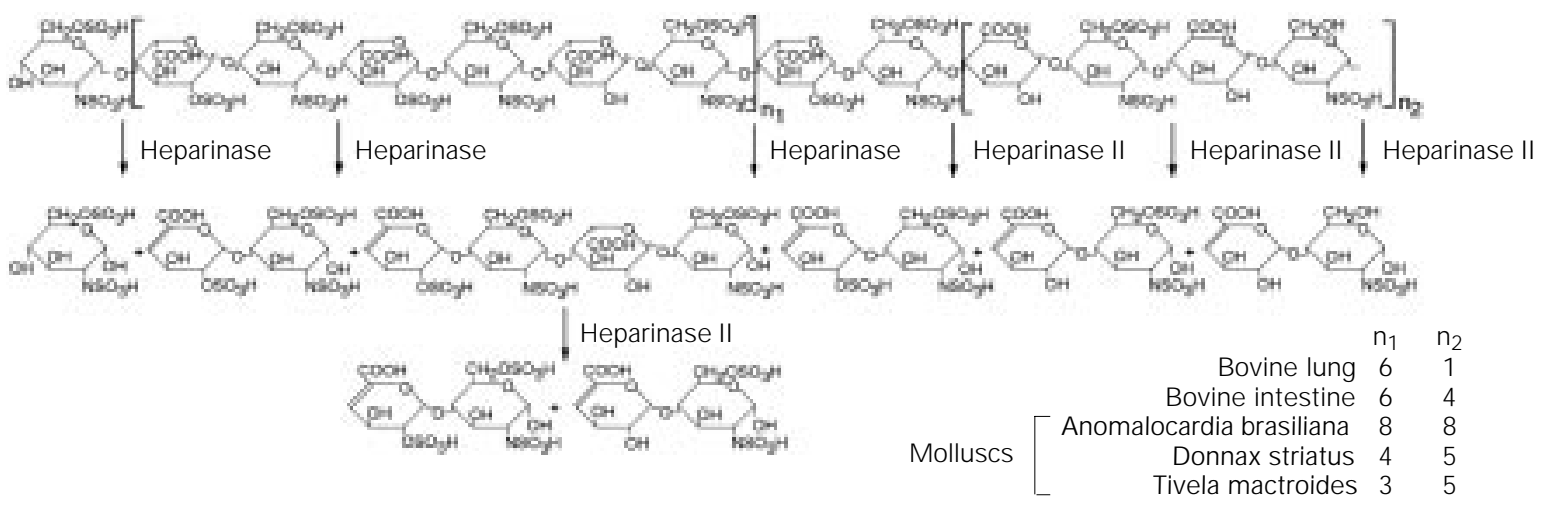

Figure 9 - Proposed structure of heparin in mammals and invertebrates. 
Figure $10-\left[{ }^{13} \mathrm{C}\right]-\mathrm{NMR}$ of mammalian and mollusc heparins.
Tivela mactroides

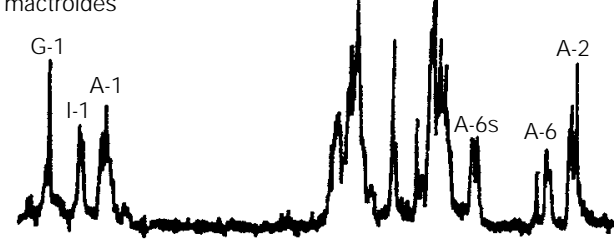

Anomalocardia brasiliana

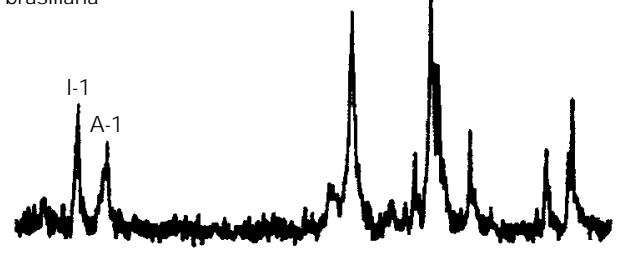

Bovine

lung

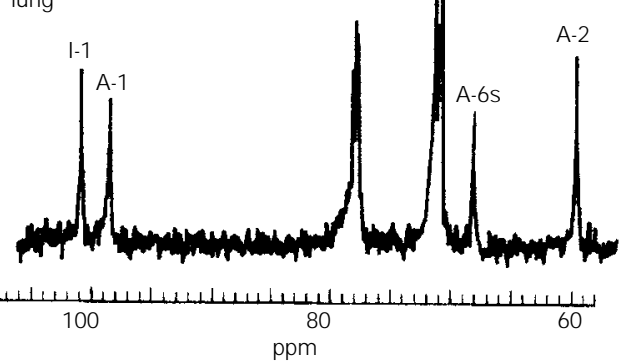

$\left[{ }^{13} \mathrm{C}\right]-\mathrm{NMR}$ spectroscopy (see below). The length and abundance of these two regions vary according to the origin of heparin. Thus, bovine lung heparin is extremely rich in the region susceptible to heparinase (36), whereas bovine intestinal heparin and mollusc heparins contain significant amounts of the region susceptible to heparitinase II (3741). The estimated abundance of the two regions is shown in Figure 9. Besides the disaccharides depicted in the figure, other disaccharide units which occur in small amounts in the molecule have been identified such as disaccharides containing 3-O sulfated residues in the glucosamine moiety (42) and N-acetylated glucosamine (43).

Besides being susceptible to specific enzymes the heparin from Anomalocardia brasiliana possesses all the other properties characteristic of heparin such as anticoagulant and other pharmacological activities $(38,40)$ and chemical degradation (38). NMR spectroscopy has shown that the mollusc
Figure 11 - $\left[{ }^{1} \mathrm{H}\right]-N M R$ of IdoA,2SGlcNS,6S formed from mammalian and mollusc heparin by action of heparinase. Upper panel, Mammalian heparin; lower panel, mollusc heparin.

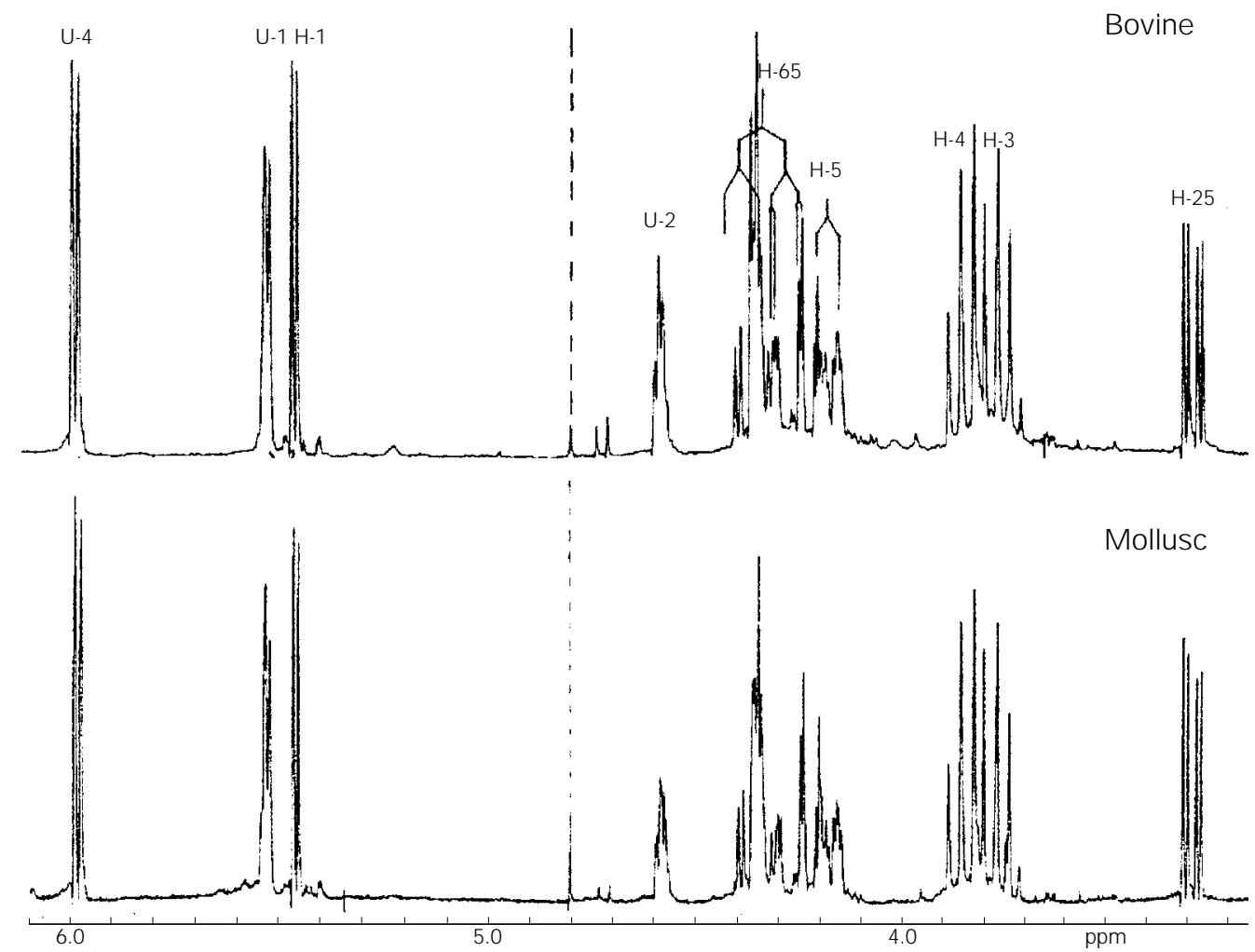


heparin was undistinguishable from those of mammalian origin (41). Figure 10 shows the $\left[{ }^{13} \mathrm{C}\right]-\mathrm{NMR}$ spectroscopy of heparins obtained from two species of molluscs compared to a mammalian heparin. Note that the main chemical shifts are present in the mammalian and mollusc heparins. The one derived from Tivela mactroides also contains signals attributed to the nonsulfated uronic acid residues. The $\left[{ }^{1} \mathrm{H}\right]-\mathrm{NMR}$ spectroscopy of the main repeating disaccharide unit obtained from mollusc and mammalian heparin by heparinase shown in Figure 11 indicates that they contain the same signals with identical chemical shifts, confirming the identity of these heparins.

\section{Conclusions}

These studies indicate that heparan sulfate is a ubiquitous compound of animal cells, whose structure has been maintained throughout evolution, showing an enormous variability regarding the relative amounts of its disaccharide units. Heparin, on the other hand, is present only in a few tissues and species of the animal kingdom in the form of granules inside organelles in the cytoplasm of special cells. Thus, the distribution as well as the main structural features of the molecule, including its main disaccharide unit, have been maintained throughout evolution.

These and other studies $(9,44,45)$ have led to the proposal that heparan sulfate may be involved in the cell-cell recognition phenomena and control of cell growth, whereas heparin may be involved in defense mechanisms against bacteria and other foreign materials (31). All indications obtained so far suggest that these molecules perform the same functions in vertebrates and invertebrates.

\section{References}

1. Dietrich CP \& Nader HB (1974). Fractionation and properties of four heparitin sulfates from beef lung tissue. Isolation and characterization of a homogeneous species of heparitin sulfate. Biochimica et Biophysica Acta, 345: 34-44.

2. Silva ME \& Dietrich CP (1974). Isolation and partial characterization of three induced enzymes from Flavobacterium heparinum involved in the degradation of heparin and heparitin sulfates. Biochemical and Biophysical Research Communications, 56: 965-972 .

3. Linker A (1975). The uronidic linkages in heparitin sulfate. Connective Tissue Research, 3: 33-37.

4. Linker A \& Hovingh P (1975). Structural studies of heparitin sulfates. Biochimica et Biophysica Acta, 385: 324-333.

5. Linker $A \&$ Hovingh $P$ (1977). The uses of degradative enzymes as tools for identification and structural analysis of glycosaminoglycans. Federation Proceedings, 36: 43-46.

6. Linker A (1979). Structure of heparan sulphate oligosaccharides and their degradation by exo-enzymes. Biochemical J ournal, 183: 711-720.
7. Dietrich CP, Nader HB \& Straus AH (1983). Structural differences of heparan sulfates according to the tissue and species of origin. Biochemical and Biophysical Research Communications, 111: 865-871.

8. Tersariol ILS, Ferreira TMPC, Medeiros MGL, Porcionatto MA, Moraes AC, Abreu, LRD, Nader HB \& Dietrich CP (1994). Sequencing of heparan sulfate proteoglycans: Identification of variable and constant oligosaccharide regions in eight heparan sulfate proteoglycans from different origins. Brazilian J ournal of Medical and Biological Research, 27: 2097-2102.

9. Dietrich CP (1984). A model for cell-cell recognition and control of cell growth mediated by sulfated glycosaminoglycans. Brazilian J ournal of Medical and Biological Research, 17: 5-15.

10. Maccarana $M$, Sakura $Y$, Tawada A, Yoshida K \& Lindahl U (1990). Domain structure of heparan sulfates from bovine organs. J ournal of Biological Chemistry, 271: 17804-17810.

11. Nader HB, Dietrich CP, Buonassisi $V \&$ Colburn P (1987). Heparin sequences in the heparan sulfate chains of an endothelial cell proteoglycan. Proceedings of the
National Academy of Sciences, USA, 84: 3565-3569.

12. Lyon M, Deakin J \& Gallagher JT (1994). Liver heparan sulfate structure: a novel molecular design. Journal of Biological Chemistry, 269: 11208-11215.

13. Dietrich CP, Tersariol ILS, Toma L, Moraes CT, Porcionatto MA, Oliveira FW \& Nader HB (1998). Sequencing of heparan sulfate: Identification of variable and constant oligosaccharide regions in eight heparan sulfates from different origins. Cellular and Molecular Biology, 44: 417-429.

14. Toma L, Dietrich CP \& Nader HB (1996). Differences in the non-reducing ends of heparan sulfates excreted by patients with mucopolysaccharidoses revealed by bacterial heparitinases: A new tool for structural studies and differential diagnosis of Sanfilippo's and Hunter's syndromes. Laboratory Investigation, 75: 771-781.

15. Cassaro CMF \& Dietrich CP (1977). The distribution of sulfated mucopolysaccharides in invertebrates. J ournal of Biological Chemistry, 252: 2254-2261.

16. Katzman RL \& J eanloz RW (1969). Acid polysaccharides from invertebrate con- 
nective tissue: phylogenetic aspects. Science, 166: 758-759.

17. Rahemtulla F \& Løvtrup S (1974). The comparative biochemistry of invertebrate mucopolysaccharides. II. Nematoda; Annelida. Comparative Biochemistry and Physiology, B, 49: 639-646.

18. Rahemtulla F \& Løvtrup S (1974). The comparative biochemistry of invertebrate mucopolysaccharides. I. Methods; Platyhelminthes. Comparative Biochemistry and Physiology, B, 49: 631-637.

19. Rahemtulla F \& Løvtrup S (1975). The comparative biochemistry of invertebrate mucopolysaccharides. III. Oligocheta and Hirudinea. Comparative Biochemistry and Physiology, B, 50: 627-629.

20. Rahemtulla F \& Løvtrup S (1975). The comparative biochemistry of invertebrate mucopolysaccharides. Bivalvia. Phylogenetic implications. Comparative Biochemistry and Physiology, B, 50: 631-635.

21. Rahemtulla F, Hoglund NG \& Løvtrup S (1976). Acid mucopolysaccharides in the skin of some lower vertebrates (hagfish, lamprey and Chimaera). Comparative Biochemistry and Physiology, B, 53: 295-298.

22. Person P \& Mathews MB (1967). Endoskeletal cartilage in a marine polychaete, Eudistylia polymorpha. Biological Bulletin, 132: 244-252.

23. Hoglund $L$ (1976). The comparative biochemistry of invertebrate mucopolysaccharides. V. Insecta (Calliphora erythrocephala). Comparative Biochemistry and Physiology, B, 53: 9-14.

24. Hovingh $P \&$ Linker $A$ (1982). An unusual heparan sulfate isolated from lobsters (Homarus americanus). J ournal of Biological Chemistry, 257: 9840-9844.

25. Dietrich $C P$, Paiva VMP, J erônimo SMB, Ferreira J MOC, Medeiros MGL, Paiva J F \& Nader HB (1983). Characteristic distribution of heparan sulfates and chondroitin sulfates in tissues and organs of the Ampularidae Pomacea sp. Comparative Biochemistry and Physiology, 768: 695698.

26. Nader HB, Medeiros M GL, Paiva J F, Paiva VMP, J erônimo SMB, Ferreira TMPC \& Dietrich CP (1983). A correlation between the sulfated glycosaminoglycan concentration and degree of salinity of the habitat in fifteen species of the classes Crustacea, Pelecypoda and Gastropoda. Comparative Biochemistry and Physiology, 76: 433-436.

27. Nader HB, Ferreira TMPC, Paiva J F, Medeiros MGL, J erônimo SMB, Paiva VMPP \& Dietrich CP (1984). Isolation and structural studies of heparan sulfates and chondroitin sulfates from three species of molluscs. J ournal of Biological Chemistry, 259: 1431-1435.

28. Nader HB, Ferreira TMPC, Chavante SF, Toma L, Dietrich CP, Casu B \& Torri G (1988). Maintenance of heparan sulfate structure through evolution. Chemical, enzymic degradation and ${ }^{13}$ C N.M.R. spectral evidence. Carbohydrate Research, 184: 292-300.

29. Ferreira TMPC, Medeiros MGL, Dietrich CP \& Nader HB (1993). Structure of heparan sulfate from the fresh water mollusc Anomantidae sp: sequencing of its disaccharide units. International J ournal of Biochemistry, 25: 1219-1225.

30. Chavante SF, Santos EA, Oliveira FW, Fernandes J KH, Guerrini M, Torri G \& Dietrich CP (1997). An unusual heparan sulfate isolated from the brine shrimp Artemia franciscana. XXV Annual Meeting of the Sociedade Brasileira de Bioquímica e Biologia Molecular, May 36, Caxambu, MG, 101 (Abstract).

31. Nader HB \& Dietrich CP (1989). Natural occurrence and possible biological role of heparin. In: Lane DA and Lindahl U (Editors), Heparin: Chemical and Biological Properties, Clinical Applications. Edward Arnold Publishers, London.

32. Gomes PB \& Dietrich CP (1982). Distribution of heparin and other sulfated glycosaminoglycans in vertebrates. Comparative Biochemistry and Physiology, 73: 857-864.

33. Burson SL, Fahrenbach MJ , Frommhagen LH, Riccardi BA, Brown RA, Brockman J A, Lewry HV \& Stockstad ELR (1956). Isolation and purification of mactins, heparin-like anticoagulants from mollusca. J ournal of the American Chemical Society, 78: 5874-5878.

34. Rahemtulla F \& Løvtrup S (1976). The comparative biochemistry of invertebrate mucopolysaccharides. V. Mollusca. Comparative Biochemistry and Physiology, B, 53: 15-18.

35. Santos EA (1997). Heparina do molusco Anomalocardia brasiliana: A. Natureza dos resíduos de ácidos urônicos. B. Distribuição em tecidos e correlação com "mastócitos". Doctoral thesis, UNIFESP, São Paulo, SP.

36. Silva ME \& Dietrich CP (1975). The structure of heparin. Characterization of the products formed from heparin by the action of a heparinase and a heparitinase from Flavobacterium heparinum. J ournal of Biological Chemistry, 250: 6841-6846.
37. Bianchini $P$, Osima B, Parma B, Dietrich CP, Takahashi HK \& Nader HB (1985). Structural studies and in vitro and in vivo pharmacological activities of heparin fractions and fragments prepared by chemical and enzymic depolymerization. Thrombosis Research, 40: 49-58.

38. Dietrich CP, Paiva J F, Moraes CT, Takahashi HK, Porcionatto MA \& Nader HB (1985). Isolation and characterization of a heparin with high anticoagulant activity from Anomalocardia brasiliana. Biochimica et Biophysica Acta, 843: 1-7.

39. Pejler G, Danielsson A, Bjork I, Lindahl U, Dietrich CP \& Nader HB (1987). Structure and antithrombin-binding properties of heparin isolated from the clams Anomalocardia brasiliana and Tivela mactroides. J ournal of Biological Chemistry, 262: 1413-1421.

40. Paiva J F, Santos EA, J eske W, Fareed J Nader HB \& Dietrich CP (1995). A comparative study on the mechanism of the anticoagulant action of mollusc and mammalian heparins. Comparative Biochemistry and Physiology, 111: 495-499.

41. Dietrich CP, Nader HB, Paiva J F, Tersariol ILS, Santos EA, Holme KR \& Perlin AS (1989). Heparin in molluscs: Chemical, enzymatic degradation and ${ }^{13} \mathrm{C},{ }^{1} \mathrm{H}$ NMR spectroscopical evidence for the maintenance of the structure through evolution. International J ournal of Biological Macromolecules, 11: 361-366

42. Lindahl $\mathrm{U}$, Thunberg $\mathrm{L}$, Backstrom G, Riesenfeld J , Nordling K \& Bjork I (1984). Extension and structural variability of the antithrombin-binding sequence in heparin. J ournal of Biological Chemistry, 259: 12368-12376.

43. Rosenberg RD \& Lam L (1979). Correlation between structure and function of heparin. Proceedings of the National Academy of Sciences, USA, 76: 12181222

44. Porcionatto MA, Pinto CRM, Dietrich CP \& Nader HB (1994). Heparan sulfate proteoglycan and control of cell proliferation: enhanced synthesis induced by phorbol ester (PMA) during $\mathrm{G}_{1}$-phase. Brazilian J ournal of Medical and Biological Research, 27: 2185-2190.

45. Porcionatto MA, Moreira CR, Armelin HA Dietrich CP \& Nader HB (1998). Stimulation of heparan sulfate proteoglycan synthesis and secretion during $G_{1}$ phase induced by growth factors and PMA. J ournal of Cellular Biochemistry, 70: 563-572. 